\title{
Mu and Delta Opiate Receptors Coupled Negatively to Adenylate Cyclase on Embryonic Neurons from the Mouse Striatum in Primary Cultures
}

\author{
Hervé Chneiweiss, Jacques Glowinski, and Joël Premont \\ Chaire de Neuropharmacologie, INSERM U 114, Collège de France, 75231 Paris Cedex 05, France
}

Primary cultures of pure populations of neuronal or glial cells from the striatum, the cerebral cortex, and the mesencephalon of the mouse embryo were used to look for the presence of opiate receptors coupled to adenylate cyclase. Leu-enkephalin inhibited cAMP production in membranes of embryonic striatal neurons but not in those of other cell types examined. Mu and delta opiate receptors seemed to be coupled negatively to adenylate cyclase in embryonic striatal neurons. It was found that DTLET (a selective delta agonist), as well as DAGO (a selective mu agonist), inhibited cAMP production on these cells. DTLET but not, however, DAGO produced a similar effect on homogenates from the adult rat striatum and on membranes from the neuroblastoma $\times$ glioma hybrid cell line NG 108-15, two preparations known to possess only delta receptors negatively coupled to adenylate cyclase. The selective kappa agonist $U \mathbf{5 0 . 4 8 8}$ was ineffective on all types of membrane preparations used.

The inhibitory effects of both DTLET and DAGO on basal adenylate cyclase activity in striatal neurons were reversed by naloxone with a similar efficacy. Two other selective mu agonists, trimu 5 and morphiceptin, inhibited cAMP production in membranes of striatal neurons as well. The nonadditivity of the inhibitory effects of DTLET and DAGO on basal or forskolin-induced activation of adenylate cyclase suggested that mu and delta receptors were colocalized on a similar subpopulation of striatal cells in primary culture. These cells possess dopaminergic receptors of the D1 subtype as well since the amplitude of the inhibitory effects of DTLET and DAGO on CAMP production was increased in the presence of dopamine. The inhibitory effects of DAGO or DTLET and of somatostatin on adenylate cyclase activity were additive, suggesting that somatostatin receptors coupled negatively to the enzyme may not be localized on striatal neurons possessing $\mathrm{mu}$ and delta receptors.

In previous studies, we have used primary cultures of cells from the cerebral cortex, the striatum, and the mesencephalon of mouse embryos in order to characterize and define the cellular localization or colocalization of receptors coupled to adenylate

\footnotetext{
Received Oct. 21, 1987; revised Dec. 28, 1987; accepted Dec. 30, 1987.

We would like to thank particularly Dr. B. Roques and J. M. Zajac for their generous gifts of $\mathrm{mu}$, delta, and kappa receptor agonists and for stimulating and fruitful discussions. This rescarch was supported by INSERM, DRET (Contract 85.078) and Rhône Poulenc Santé.

Correspondence should be addressed to Dr. H. Chneiweiss, Chaire de Neuropharmacologie, INSERM U 114, Collège de France, 11, place Marcelin Berthelot, 75231 Paris Cedex 05, France.

Copyright (C) 1988 Society for Neuroscience $0270-6474 / 88 / 093376-07 \$ 02.00 / 0$
}

cyclase. Using this approach, adenylate cyclases sensitive to biogenic amines and peptide receptors coupled positively or negatively to the enzyme [vasoactive intestinal peptide (VIP) and somatostatin receptors, respectively] were characterized on pure neuronal populations (Premont et al., 1983; Chneiweiss et al., 1984, 1985a, b, 1986, 1987). In addition, besides $\beta$-adrenergic receptors, VIP, and somatostatin receptors coupled to adenylate cyclase could be demonstrated on pure astrocytes (Chneiweiss et al., 1984, 1985a , b, 1986). Differences in the localization of the receptors were seen from one structure to another either on neurons or on glial cells. Finally, information concerning the eventual colocalization of distinct types of receptors on the same cellular population was obtained by determining whether the effects of the corresponding agonists on cAMP production in membrane preparations were additive. For example, all striatal neurons possessing dopamine D1 receptors were also found to possess VIP receptors coupled to adenylate cyclase (Chneiweiss et al., 1985a). The present investigation was undertaken to determine if opioid receptors coupled to adenylate cyclase were present on either neurons or astrocytes from the cerebral cortex, the striatum, and the mesencephalon of mouse embryos in primary culture.

Binding studies on tissues of the adult brain of various species have distinguished 3 main classes of opioids binding sites: $\mathrm{mu}$, delta, and kappa binding sites, which can be recognized by specific ligands or endogenous opioid peptides (Lord et al., 1977; Paterson et al., 1983; Simon, 1987). Morphine and the synthetic peptide $\left[\mathrm{D}-\mathrm{Ala}^{2},(\mathrm{Me}) \mathrm{Phe}^{4}, \mathrm{Gly}(\mathrm{OH})^{5}\right]$ enkephalin (DAGO) are selective ligands for mu binding sites (Handa et al., 1981). (D$\mathrm{Thr}^{2}, \mathrm{Leu}^{5}$, Thr ${ }^{6}$ ) enkephalin (DTLET) is one of the most specific ligands for the delta binding sites (Zajac and Roques, 1985). Kappa binding sites are recognized in particular by the alkaloid U 50.488 (Piercey et al., 1982). Among pro-enkephalin-derived peptides (Mets)-enkephalin is delta selective, the pro-opiomelanocortin derived beta-endorphin is equipotent at mu and delta sites, while the opioids derived from the prodynorphin molecule are largely kappa-opiate receptor selective (Martin, 1984; Leslie, 1987). It is now well established that the delta receptor is coupled negatively to adenylate cyclase, as has been shown particularly on the neuroblastoma $\times$ glioma hybrid cell line NG 108-15 (Sharma et al., 1975; Law ct al., 1981, 1985). Mu and delta receptors have also been shown in both central and peripheral neurons to increase potassium conductance and therefore to reduce calcium entry indirectly, whereas kappa receptors seem to reduce calcium currents directly (North, 1986). Using selective ligands we show that, among all cell types examined, the embryonic striatal neurons in primary culture are the only ones 
Table 1. Inhibition of adenylate cyclase activity by leu-enkephalin on adult rat striatum, mouse striatal neurons and astrocytes in primary culture

\begin{tabular}{lcc} 
& \multicolumn{2}{c}{$\begin{array}{l}\text { Adenylate cyclase activity } \\
\text { (pmol cAMP/10 min/mg protein) }\end{array}$} \\
\cline { 2 - 3 } Tissue & Basal & $\begin{array}{c}\text { +Leu-ENK } \\
\left(10^{-6} \mathrm{M}\right)\end{array}$ \\
\hline Adult striatum & $975 \pm 56$ & $737 \pm 62^{*}$ \\
Neurons & & \\
$\quad$ Cerebral cortex & $19 \pm 3$ & $20 \pm 3$ \\
$\quad$ Striatum & $69 \pm 12$ & $48 \pm 7^{*}$ \\
$\quad$ Mesencephalon & $24 \pm 4$ & $22 \pm 5$ \\
Astrocytes & & \\
$\quad$ Cerebral cortex & $49 \pm 7$ & $53 \pm 5$ \\
$\quad$ Striatum & $9 \pm 1$ & $9 \pm 1$ \\
$\quad$ Mesencephalon & $101 \pm 9$ & $97 \pm 7$
\end{tabular}

Effect of leu-enkephalin (leu-ENK) on adenylate cyclase activity was determined on adult rat striatal membranes and homogenates from neurons or glial cells grown in primary culture originating from 3 brain areas of the mouse embryo. Inhibition of cAMP production due to leu-enkephalin was found only in the adult striatum and in striatal neurons $\left({ }^{*} p<0.005\right.$ as estimated by Student's $t$ test; $n=4$ ). Fach value is the mean \pm SEM of data obtained in 4 experiments, each individual experiment being performed with triplicate determinations.

possessing delta receptors coupled negatively to adenylate cyclase. Surprisingly, mu agonists were also found to inhibit markedly adenylate cyclase activity on striatal neurons. Additivity experiments suggested that the delta and mu receptors were colocalized on striatal neurons. They also revealed that these opiate receptors could be colocalized also with D1 dopaminergic (DA) but not somatostatin receptors on a population of striatal neurons.

\section{Materials and Methods}

Neuronal primary cultures. Cortical and striatal cells $\left(20 \times 10^{6}\right.$ each $)$ from 16-d-old Swiss mouse embryos (Iffa Credo) and mesencephalic cells from 14-d-old mouse embryos were dissociated and plated in the absence of fetal calf serum in culture dishes $(100 \mathrm{~mm}$ diameter, Falcon)

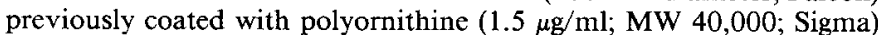
as already described (Di Porzio et al., 1980). The culture medium consisted of a mixture (1:1) of modified Eagle's medium (MEM) and F-12 nutrient (Gibco), supplemented with glucose ( $33 \mathrm{~mm}$ ), glutamine ( $2 \mathrm{mM}$ ), sodium bicarbonate $(3 \mathrm{~mm})$, and Hepes ( $5 \mathrm{~mm}$; Sigma). Fetal calf serum was replaced by a mixture of hormones, proteins, and salts composed of insulin ( $25 \mu \mathrm{g} / \mathrm{ml}$; Sigma), transferrin (100 $\mu \mathrm{g} / \mathrm{ml}$; Sigma), progesterone ( $20 \mathrm{nM}$; Merck), putrescine ( $60 \mu \mathrm{M}$; Sigma), and selenium salt $\mathrm{NaSeO}_{3}$ (30 nM; Merck). Under these conditions, according to different morphological and histochemical criteria, the number of non-neuronal cells is reduced to less than $5 \%$ of the cell population after $7 \mathrm{~d}$ in vitro (Prochiantz et al., 1982).

Glial primary cultures. The protocol chosen for neurons was also used to start the glial cultures. However, the medium included $10 \% \mathrm{Nu}$ serum (Collaborative Research) and was changed every $3 \mathrm{~d}$ for 4 weeks until glial elements had formed a confluent monolayer, devoid of neuronal cells. As previously described, the absence of surviving neurons was checked by indirect immunofluorescence using an antibody against the $70 \mathrm{~K}$ neurofilament protein (Chneiweiss et al., 1985b). More than $95 \%$ of the cells could be stained significantly by the immunofluorescence technique using a rabbit antibody directed against glial fibrillary acidic protein (GFAP), indicating that cells were mainly mature astrocytes. A monoclonal antibody from the rat against galactocerebroside and a rabbit antiserum against fibronectin were used to identify the presence of oligodendrocytes and fibroblasts, respectively. No staining could be observed, indicating a lack of these cell types in the cultures. The cultures also were checked to confirm the absence of macrophages using a nonspecific fluorescent immunoglobulin.

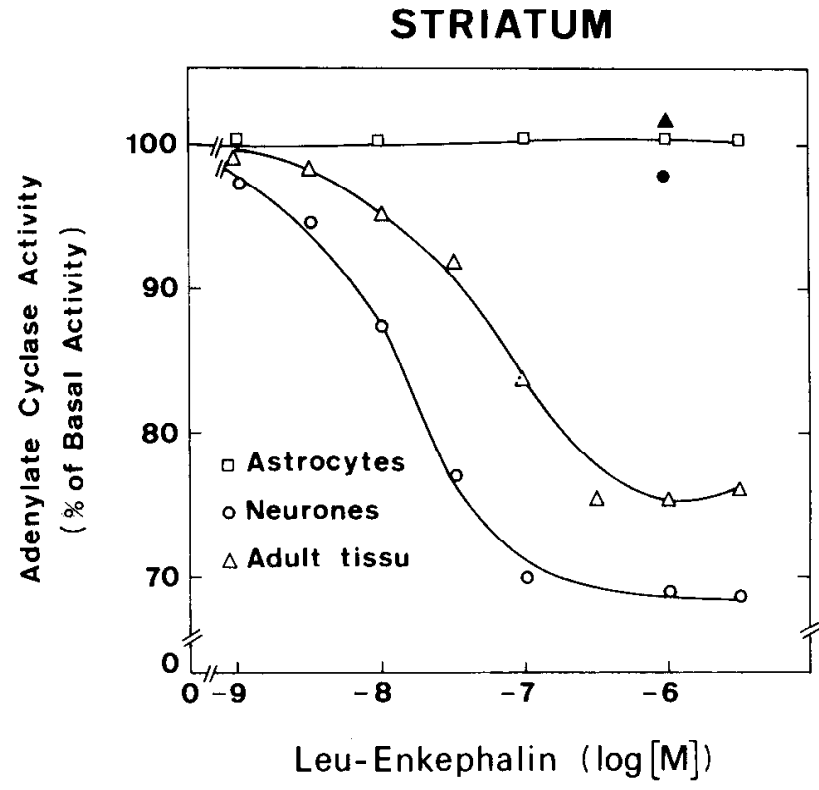

Figure 1. Inhibitory effects of leu-enkephalin on basal adenylate cyclase activity in embryonic striatal neurons from the mouse and on adult striatal tissues of the rat. Homogenates of striatal neurons and of astrocytes in primary culture and crude membranes from adult striatal tissue were prepared as described in Materials and Methods. Leu-enkephalin inhibited basal adenylate cyclase activity in striatal neurons $(O)$ and adult striatal tissue $(\triangle)$ but not in striatal astrocytes $(\square)$. The inhibitory effects were reversed by naloxone $10^{-4} \mathrm{M}(\boldsymbol{O})$. Naloxone alone induced a $12 \%$ decrease in adenylate cyclase activity when used at $10^{-4} \mathbf{M}$. Since SEMs never exceeded $5 \%$ of the mean value, they are not indicated. Basal adenylate cyclase activity (in pmol $/ 10 \mathrm{~min} / \mathrm{mg}$ protein): striatal neurons, $66 \pm 2$; striatal astrocytes, $9.1 \pm 0.8$; adult striatum, $747 \pm 53$.

Neuroblastoma-glioma hybrid, NG 108-15. The hybrid cells were cultured in Dulbecco's MEM containing HAT $(0.1$ mM hypoxanthine, $0.4 \mu \mathrm{M}$ aminopterin, $16 \mu \mathrm{M}$ thymidine), sodium bicarbonate ( $3 \mathrm{~mm}$ ), and $10 \%$ fetal calf serum. The cells were grown for 1 week after seeding before use in the experiments.

Homogenate preparation. Following 5-6 d for neuronal cells, 1 week for NG 108-15 cells, and 4 weeks for glial cells, the culture medium was removed and the cells were washed 4 times at room temperature with an isotonic solution (50 mM Tris maleate, $10 \%$ sucrose, $\mathrm{pH} 7.2$; $\mathrm{wt} / \mathrm{vol})$. A further $1.5 \mathrm{ml}$ of the same buffer was then added, and the cells $\left(20 \times 10^{6}\right)$ were detached using a rubber policeman. The resulting suspension was then homogenized at $4^{\circ} \mathrm{C}$ by 5 strokes of a Teflon pestle in a Potter Elvehjem glass homogenizer. Homogenates were directly used for adenylate cyclase assay since results were similar to those obtained with crude washed membranes (centrifugation at $100,000 \times$ $g, 15 \mathrm{~min}$ ).

Membranes from the striata of Sprague-Dawley adult male rats and Swiss adult female mouse were also used. For this purpose, striata were dissected at $4^{\circ} \mathrm{C}$ according to the technique of Glowinski and Iversen (1966), and striatal homogenates were prepared as just described for cells in culture. Particulate fractions $(100,000 \times \mathrm{g}, 15 \mathrm{~min})$ were resuspended and washed twice before the adenylate cyclase assay.

Adenylate cyclase assay. The reaction was initiated by adding $20 \mu \mathrm{l}$ of the homogenates (5-15 $\mu$ g protein) to $40 \mu \mathrm{l}$ of the incubation medium [Tris maleate, $50 \mathrm{~mm} ; \mathrm{MgSO}_{4}, 0.5 \mathrm{~mm}$; ATP, $0.05 \mathrm{~mm}$; phosphocreatine, $20 \mathrm{~mm}$; creatine kinase, $0.2 \mathrm{mg} / \mathrm{ml}$; BSA fraction $\mathrm{V}$, fatty acid free, 2.5 $\mathrm{mg} / \mathrm{ml}$; 3-isobutyl-1-methylxanthine (IBMX) $0.1 \mathrm{mM}$; GTP, $10 \mu \mathrm{M}$; papaverine, $0.1 \mathrm{mM}$; $\left(\alpha^{32} \mathrm{P}\right)$-ATP, $1 \mu \mathrm{Ci}$; ${ }^{3} \mathrm{H}-\mathrm{cAMP}, 0.002 \mu \mathrm{Ci}$, pH 7.2]. The membranes were incubated at $30^{\circ} \mathrm{C}$ for $10 \mathrm{~min}$, and the reaction ended by the addition of $100 \mu \mathrm{l}$ of a medium containing sodium dodecyl sulfate, 1\% (wt/vol); ATP, $5 \mathrm{~mm}$; cAMP, $2 \mathrm{~mm}$; Tris $\mathrm{HCl}, 50 \mathrm{~mm}$, pH 7.2. The ${ }^{32} \mathrm{P}$-cAMP formed was isolated according to Salomon et al. (1974). All determinations were performed in triplicatc, whosc internal variability was always less than $5 \%$ of the obtained values (relative error). 
STRIATAL NEURONES

Figure 2. Inhibitory effects of $\mathrm{mu}$ (DAGO) and delta (DTLET) opiate agonists on basal adenylate cyclase activity in embryonic striatal neurons. Left, Dose-response curves obtained with DAGO, DTLET, and U 50.488 which are selective agonists of mu $(\mu)$, delta $(\delta)$, and kappa $(\kappa)$ opiate receptors, respectively. Right, Hofstee plots of the data obtained with DAGO and DTLET from which their apparent affinities $\left(K_{a, \text { app }}\right)$ of $4.8 \times 10^{-8}$ and $8.7 \times 10^{-8} \mathrm{M}$ for DAGO and DTLET were evaluated. Data presented illustrate results of one experiment out of 5 providing similar results. Each point is the mean of triplicale determinations.
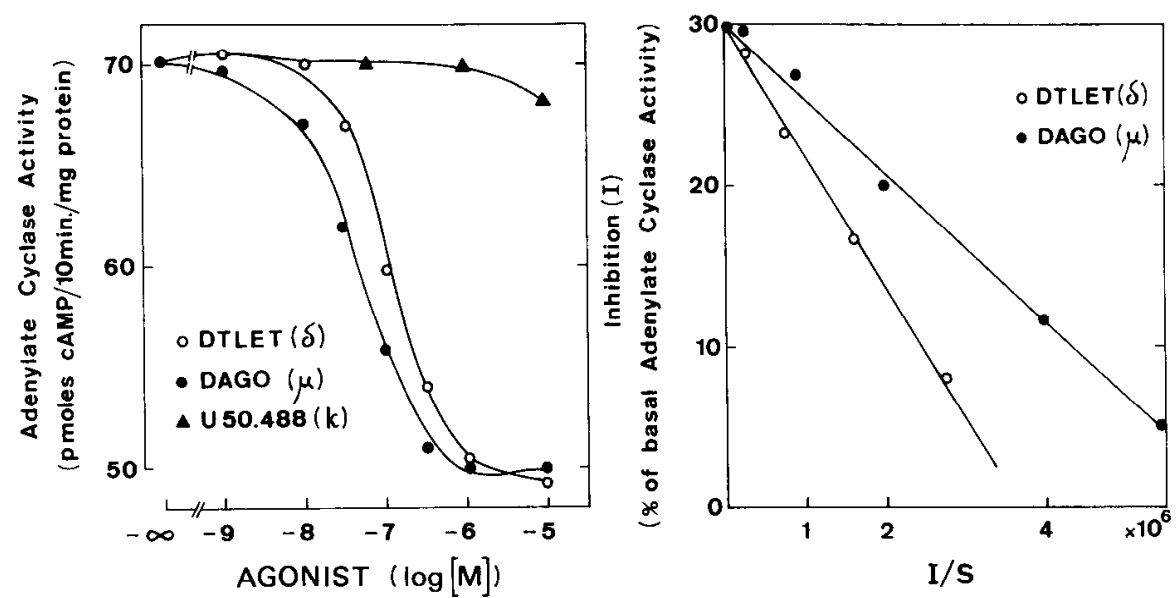

Chemicals. $\mathrm{Mu}$ and delta receptor agonists were generous gifts from Dr. B. Roques. Other chemicals were obtained from the following commercial sources: creatine kinase and creatine phosphate (Boehringer Mannheim); leu-enkephalin and somatostatin (Peninsula). All other compounds were purchased from Sigma Chemical Company and were of the highest purity available.

Radiochemicals. $\left(\alpha^{32} \mathrm{P}\right)-\mathrm{ATP}$ sodium salt $(30-40 \mathrm{Ci} / \mathrm{mmol})$ and $2-8$ ${ }^{3} \mathrm{H}$-cAMP $(25 \mathrm{Ci} / \mathrm{mmol})$ were obtained from New England Nuclear Corp.

\section{Results}

Leu-enkephalin-induced inhibition of adenylate cyclase activity in mouse embryonic striatal neurons in primary culture

Primary cultures of pure neuronal or glial cells from the cerebral cortex, mesencephalon, and striatum were used to look for an effect of leu-enkephalin on adenylate cyclase activity in membranes. As shown in Table 1, using leu-enkephalin concentrations up to $3 \times 10^{-6} \mathrm{M}$, striatal neurons were the only cells that responded to the opioid agonist, leu-enkephalin $\left(10^{-6} \mathrm{M}\right)$, producing a $30 \pm 4 \%(n=4)$ inhibition of the basal adenylate cyclase activity on striatal neuronal membranes. The maximal inhibitory effect of the peptide and its apparent affinity for its receptor on mouse embryonic striatal neurons were slightly higher than those observed on striatal homogenates from the adult rat
(Fig. 1). Naloxone $\left(10^{-4} \mathrm{M}\right)$ antagonized the leu-enkephalin inhibitory effect on both preparations (Fig. 1).

\section{Pharmacological characterization of the opioid receptor negatively coupled to adenylate cyclase on embryonic striatal neurons}

Binding studies have indicated that DAGO, DTLET, and U 50.488 are selective agonists for the $\mathrm{mu}$, delta, and kappa binding sites, respectively, in the adult brain. The kappa agonist $U$ 50.488 was without effect on adenylate cyclase activity in striatal embryonic neurons. On the other hand, DAGO and DTLET inhibited cAMP production with an almost identical efficacy (Fig. 2). Hofstee plots of the data revealed an interaction of each agonist with a single class of noninteracting receptors, their apparent affinities $\left(K_{d, \text { app }}\right)$ being very similar: DTLET, $10.8 \pm 3.3$ $\times 10^{-8} \mathrm{M}(n=5) ; \mathrm{DAGO},=3.6 \pm 0.7 \times 10^{-8} \mathrm{M}(n=5)$.

The inhibitory effects of DTLET $\left(3 \times 10^{-7} \mathrm{M}\right)$ and DAGO $(3$ $\left.\times 10^{-7} \mathbf{M}\right)$ were both antagonized by naloxone up to $3 \times 10^{-6}$ M (Fig. 3). The linear Hofstee plots of the data confirmcd that each agonist interacted with a single class of receptors. The calculated apparent affinities of naloxone for the DTLET- and DAGO-sensitive receptors were $8.5 \pm 5.3 \times 10^{-9}$ and $2.3 \pm$ $0.9 \times 10^{-9} \mathrm{M}$, respectively.
Figure 3. Antagonism by naloxone of DAGO- and DTLET-induced inhibition of adenylate cyclase activity on embryonic striatal neurons in primary cultures. Left, Increasing concentrations of naloxone reversed the inhibitory effects of DAGO $\left(3 \times 10^{-7} \mathrm{M}\right)$ and DTLET $\left(3 \times 10^{-7} \mathrm{M}\right)$ on CAMP production. Right, Hofstee plots of the data from which $\mathrm{IC}_{50}$ values of $3 \times 10^{-8}$ and $4 \times 10^{-8} \mathrm{M}$ were obtained in the presence of DAGO and DTLET, respectively. $K_{i}$ values were determined according to the formula $K_{i}=\mathrm{IC}_{50} / 1+$ $\left(\mathrm{Ag} / K_{d}\right)$ in which $\mathrm{Ag}$ is the concentration of DAGO or DTLET and $K_{d}$ their dissociation constants. Data presented correspond to results from one experiment out of three giving similar results. Each point is the mean of triplicate determinations.
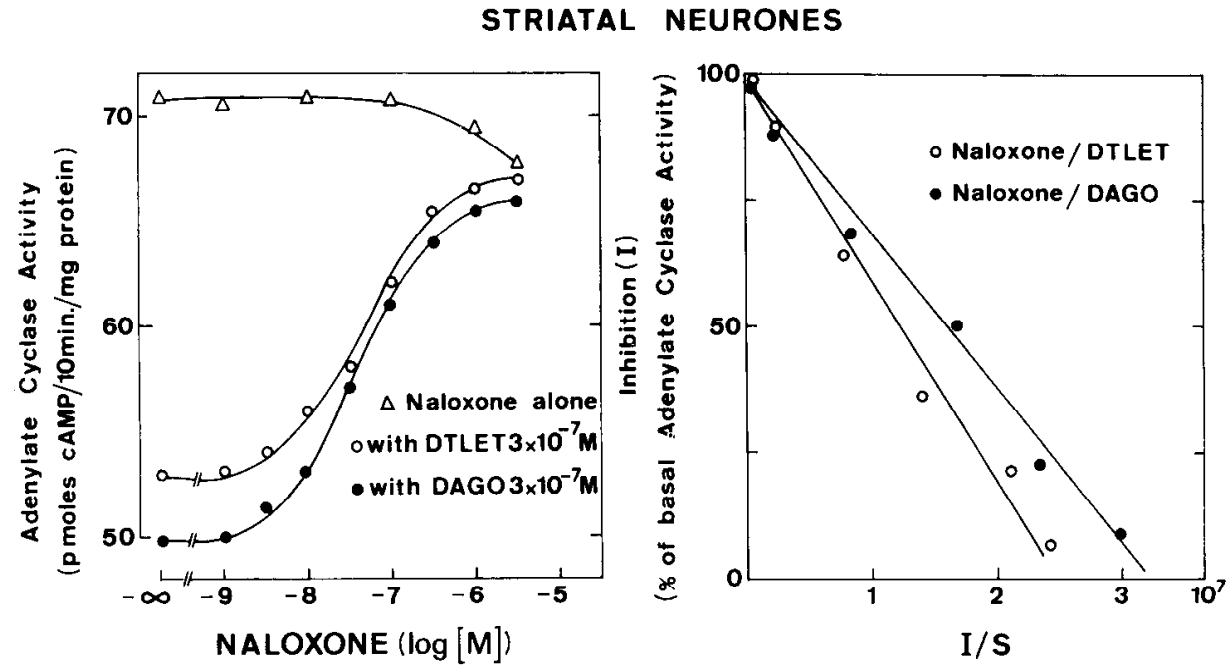


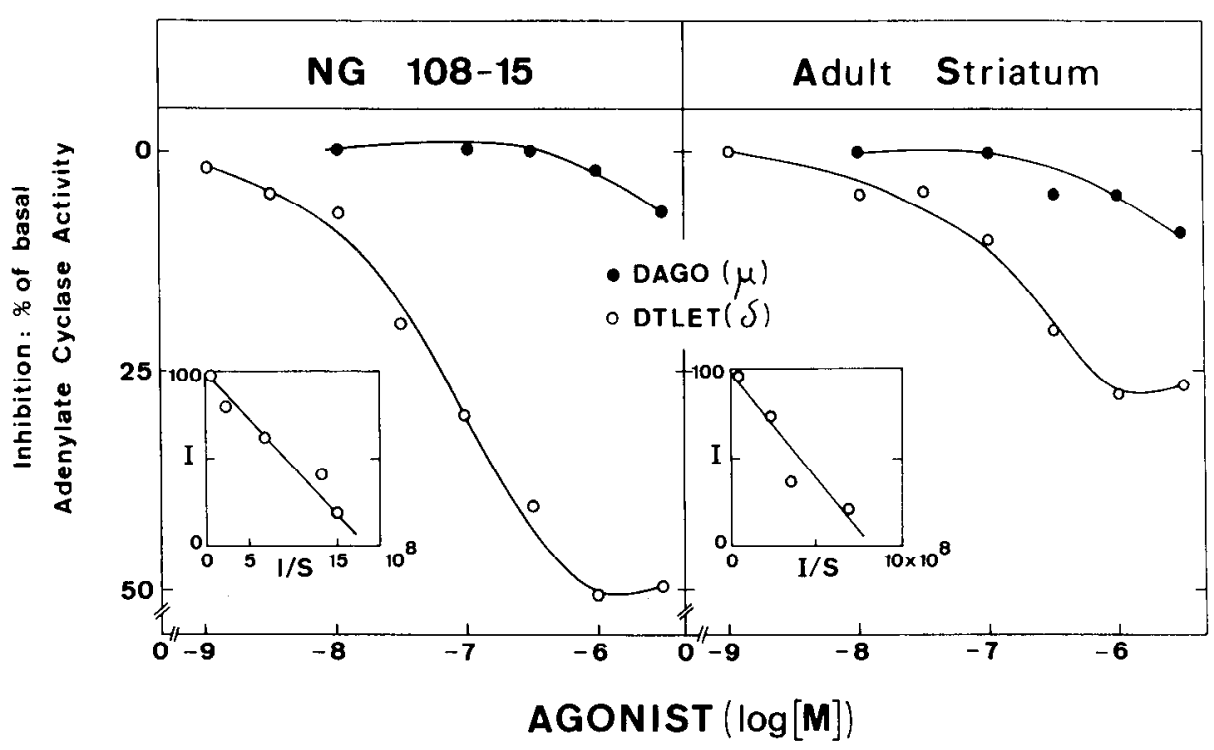

Figure 4. Comparison of the effects of DAGO and DTLET on basal adenylate cyclase activity on membranes from the neuroblastoma $\times$ glioma hybrid cell line NG 108-15 and from the rat striatum. DTLET significantly inhibited adenylate cyclase activity in both types of preparations $(54 \pm 4 \%$ and $27+2 \%$, respectively, for NG 108-15 cells and adult striatal tissue at a concentration of $10^{-6} \mathrm{M}$ ). The maximal inhibition due to DAGO on striatal membranes was always less than $12 \%$ of basal activity. Data illustrate results obtained in one experiment out of three yielding similar results. The apparent affinities of $\operatorname{DTLET}\left(K_{a \text { app }}\right): 6.3 \pm 1.2 \times 10^{-8}$ and $2.5 \pm 0.5 \times 10^{-7} \mathrm{M}$ for NG 108-15 cells and striatal adult tissue, respectively, were obtained from Hofstee plots $(n=$ $3)$.

For comparison, the effects of DTLET and of DAGO were also examined on the neuroblastoma $\times$ glioma hybrid cell line NG 108-15, which is known to possess only delta receptors. Experiments were also made on striatal homogenates of the adult rat, which possess both mu and delta binding sites and in which only delta receptors have been reported to be negatively coupled to adenylate cyclase. As illustrated in Figure 4, DTLET, but not DAGO, markedly inhibited basal adenylate cyclase activity on NG 108-15 membranes, its apparent affinity being similar to that observed on embryonic striatal neurons. DTLET was much more potent than DAGO in inhibiting cAMP production on striatal membranes of the adult rat. Naloxone antagonized the inhibitory effect of DTLET monophasically (data not shown) in both types of preparatioris, allowing the respective $\mathrm{IC}_{50}$ and $K_{i}$ values to be calculated (Table 2).

In order to determine whether the inhibitory effect of DAGO on adenylate cyclase activity in embryonic striatal neurons from the mouse was not species dependent, additional experiments were made using striatal membranes of the adult mouse. As observed on striatal membranes of the adult rat, DTLET, but not DAGO, produced a marked inhibition of cAMP production (data not shown).

Finally, 2 other potent mu agonists, trimu 5 and morphiceptin, were used and their effects up to $10^{-6} \mathrm{M}$ were tested on both homogenates from striatal neurons in culture and adult rat striatal membranes. A significant inhibition of basal adenylate cyclase activity was observed with both trimu $5(27 \pm 3 \%, n=$ 3 ) and morphiceptin $(26 \pm 4 \%, n=3)$ on neurons, whereas

Table 2. Comparison of the efficacy of naloxone in reversing inhibition of cAMP production by DTLET on striatal neurons in primary culture, NG 108-15 cells, and adult striatum

\begin{tabular}{lrc} 
Tissue & \multicolumn{1}{c}{$\mathrm{IC}_{50}(\mathrm{nM})$} & \multicolumn{1}{c}{$K_{i}(\mathrm{nM})$} \\
\hline Striatal neurons & $25 \pm 11$ & $8.5 \pm 5.3$ \\
Adult rat striatum & $34 \pm 12$ & $15.5 \pm 8.6$ \\
NG $108-15$ & $130 \pm 35$ & $22.6 \pm 10.4$
\end{tabular}

$\mathrm{IC}_{50}$ and $K_{i}$ values for naloxone were deternined from Hofstee plots. The concentration of DTLET used was $3 \times 10^{-7} \mathrm{M}$. Data are means \pm SEM of results obtained in 3 experiments. only a weak effect, close to that of DAGO, was found on striatal adult tissue $(11 \pm 2 \%$ and $8 \pm 2 \%$ for trimu 5 and morphiceptin, respectively; $n-3)$.

Cellular localization of mu and delia receptors on embryonic striatal neurons in primary culture

As previously reported (Premont et al., 1983), indications about the cellular localization of different types of receptors coupled to adenylate cyclase can be obtained by experiments which determine whether the additive effects of the corresponding agonists are present. Complete additivity of the effects of 2 distinct agonists favors a localization of the corresponding receptors on distinct cellular populations or on distinct cellular domains.

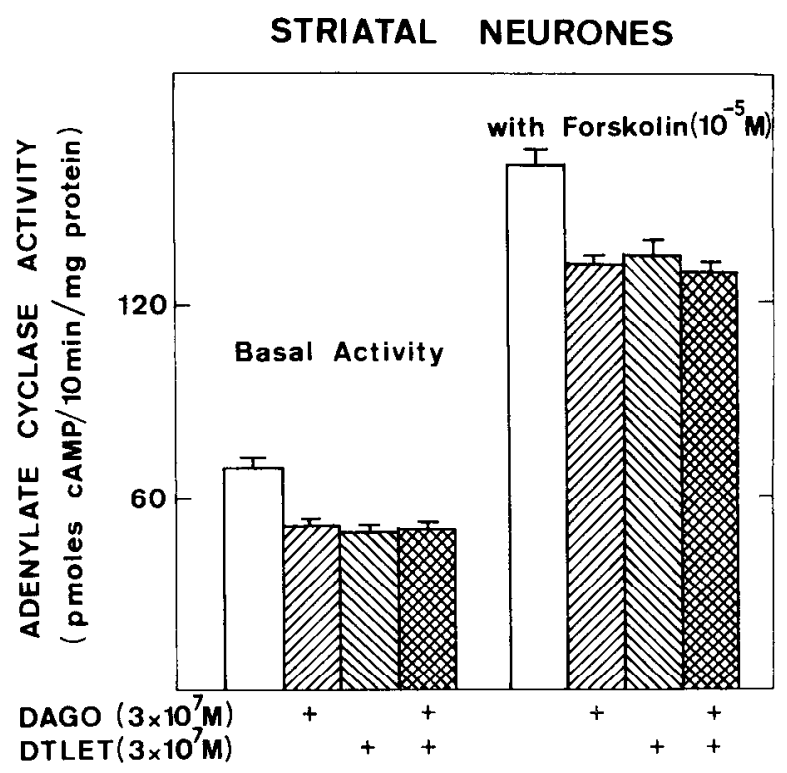

Figure 5. Nonadditivity of the inhibitory effects of DTLET and DAGO on hasal and forskolin-stimulated adenylate cyclase activity. Adenylate cyclase activity was estimated on homogenates of striatal neurons grown in primary culture in the absence or presence of forskolin, DAGO $(3 \times$ $\left.10^{-7} \mathrm{M}\right)$, and DTLET $\left(3 \times 10^{-7} \mathrm{M}\right)$ bcing addcd alone or simultaneously. Data are means \pm SEM of results obtained in 3 independent experiments. 
Figure 6. Additivity of the inhibitory effects of leu-enkephalin and somatostatin on basal adenylate cyclase activity in embryonic striatal neurons in primary culture. The inhibitory effects of somatostatin alone or in the presence of leu-enkephalin $\left(10^{-6} \mathrm{M}\right)$ (left) and of leu-enkephalin alone or in the presence of somatostatin $\left(3 \times 10^{-6} \mathrm{M}\right)($ right $)$ on homogenates of striatal neurons. Neither the maximal effect nor the apparent affinity of each peptide was affected by the presence of the other, indicating the complete additivity of thcir inhibitory effects. Data are means of results obtained in 3 independent experiments. Since SEMs were always less than $7 \%$ of the mean values, they are not represented.
STRIATAL NEURONES

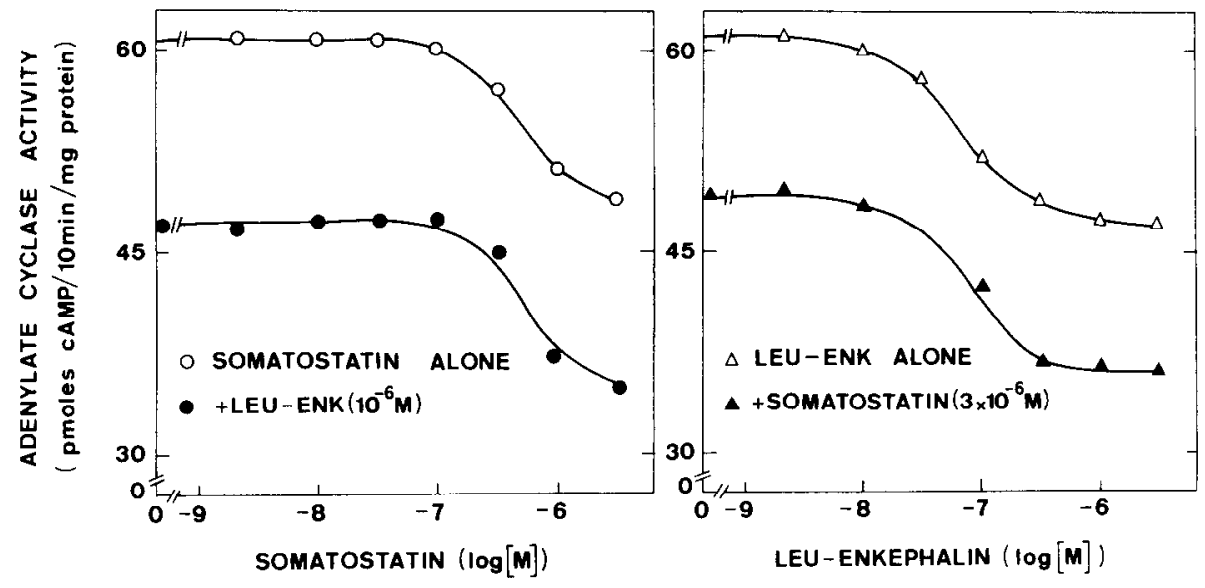

Nonadditivity demonstrates a colocalization of the 2 types of receptors on the same cells.

As shown in Figure 5, the inhibitory effects of DAGO $(3 \times$ $\left.10^{-7} \mathrm{M}\right)$ and DTLET $\left(3 \times 10^{-7} \mathrm{M}\right)$ on basal adenylate cyclase activity were nonadditive. Similar results were obtained in the presence of forskolin $\left(10^{-5} \mathrm{M}\right)$, an activator of the adenylate cyclase catalytic subunit. This result suggested that mu and delta receptors were located on the same population of striatal embryonic neurons.

Complementary experiments were made with somatostatin, which has also been shown to inhibit basal adenylate cyclase activity in embryonic striatal neurons (Chneiweiss et al., 1985b). Interestingly, the inhibitory effects of leu-enkephalin and somatostatin were completely additive (Fig. 6). These results indicate that additive inhibitory effects can be demonstrated and suggest that opiate and somatostatin receptors are not colocalized on the same population of striatal cells or on the same morphological domain of the cells.

Finally, since dopamine has been shown to modify the characteristics of the inhibitory response to somatostatin (Chneiweiss et al., 1985b), similar experiments were made using either DTLET or DAGO, or both. As previously shown, dopamine

Table 3. Potentiation by dopamine of the DTLET- and DAGOinduced decrease in CAMP production on striatal neurons in primary culture

Adenylate cyclase activity (pmol cAMP/10 cAMP production $\mathrm{min} / \mathrm{mg}$ protein)

$$
\begin{aligned}
& \text { Basal activity } \\
& + \text { DTLET }\left(10^{-6} \mathrm{M}\right) \\
& + \text { DAGO }\left(10^{-6} \mathrm{M}\right) \\
& \text { + Dopamine }\left(10^{-5} \mathrm{M}\right) \\
& + \text { Dopamine }\left(10^{-5} \mathrm{M}\right) \\
& \\
& + \text { DTLET }\left(10^{-6} \mathrm{M}\right) \\
& + \text { Dopamine }\left(10^{-5} \mathrm{M}\right) \\
& \\
& + \text { DAGO }\left(10^{-6} \mathrm{M}\right)
\end{aligned}
$$$$
68 \pm 5
$$$$
49 \pm 4(100)
$$$$
47 \pm 3(110)
$$$$
153 \pm 9
$$$$
115 \pm 7(200)
$$$$
110 \pm 8(205)
$$

Data are means \pm SEM of results obtained in 4 (DTLET) or 2 (DAGO) experiments, each independent experiment being performed in triplicate. The absolute decrease in cAMP production induced by DTLET and DAGO was $19 \pm 6$ and $21 \pm 5$ $\mathrm{pmol} \mathrm{cAMP} / 10 \mathrm{~min} / \mathrm{mg}$ protein, respectively, in the absence of dopamine and 38 \pm 6 and $43 \pm 8 \mathrm{pmol} \mathrm{cAMP} / 10 \mathrm{~min} / \mathrm{mg}$ protein in the presence of dopamine. Values in parentheses indicate percentage of the decrease in cAMP production induced by DTLET on basal activity. $\left(10^{5} \mathrm{M}\right)$ alone markedly stimulated adenylate cyclase activity. In the presence of dopamine $\left(10^{-5} \mathrm{M}\right)$, the decreases in cAMP production induced by DTLET and DAGO were about twice those observed in the absence of dopamine (Table 3). These observations favor the colocalization of opiate receptors with dopaminergic D1 receptors on a subpopulation of striatal neurons.

\section{Discussion}

The present study demonstrates that 16-d-old embryonic neurons from the mouse striatum grown for $6 \mathrm{~d}$ in primary culture possess delta opiate receptors negatively coupled to adenylate cyclase. In addition, experiments with DAGO, a selective mu agonist, suggest that mu receptors coupled negatively to the enzyme are also present on these cells. Both types of opiate receptors (mu and delta) seem to be colocalized on the same subpopulation of striatal neurons. Interestingly, leu-enkephalin, which has been shown in electrophysiologic studies to be as potent on mu and delta receptors (North, 1986), did not modify cAMP production either in embryonic neurons from the cerebral cortex or mesencephalon, or in astrocytes from the 3 brain structures examined.

As shown in the adult mouse, rat, and other species, the striatum contains both mu and delta binding sites (Quirion et al., 1983; Moskowitz and Goodman, 1984; Eghbali et al., 1987). Delta binding sites have a diffuse distribution, while the localization of mu binding sites is restricted to the striosomes (Goodman et al., 1980; Herkenham and Pert, 1981). An opiate-sensitive adenylate cyclase is present on striatal membranes (Law et al., 1981; Cooper et al., 1982) and as confirmed in the present study, delta receptors are negatively coupled to the enzyme in both adult rats and adult mice. As observed in adult animals, DTLET, a selective agonist of delta receptors (Garbay-Jaureguiberry et al., 1984) inhibited basal cAMP production in membranes of embryonic striatal neurons, and this effect was antagonized by naloxone. Although the patterns of the inhibitory responses were comparable, the apparent affinity of DTLET for the embryonic striatal delta receptors seemed to be slightly higher than that observed in the adult rat. This could be linked to the presence of supersensitive delta opiate receptors on embryonic neurons in primary culture, as has been observed with other types of receptors (Premont et al., 1983; Chneiweiss et al., 1984). However, the apparent affinity of DTLET for inhibiting adenylate cyclase activity in both embryonic neurons and adult 
striatum was lower than that reported in binding studies. Most likely, this is due to the presence of the high concentration of GTP required in the adenylate cyclase assay for coupling between the agonist receptor complex, the $G$ protein, and the catalytic subunit of adenylate cyclase (Chneiweiss et al., 1987). Such a sensitivity of opiate agonist binding to GTP has been observed previously on membranes from adult brain tissues and the neuroblastoma $\times$ glioma hybrid cell line NG 108-15 (Law et al., 1985; Zajac and Roques, 1985).

Surprisingly, DAGO, a potent selective agonist of mu receptors, which had a weak effect on striatal membranes of adult animals (rat or mouse) and no effect on the hybrid cell line NG 108-15, markedly inhibited cAMP production in membranes from embryonic striatal neurons in primary culture with an efficacy similar to that observed with DTLET. In contrast, the kappa-selective agonist U 50.488 was ineffective. The kinetic characteristics of the DAGO-induced inhibition of adenylate cyclase activity were similar to those observed with DTLET, DAGO even being slightly more potent. Naloxone, an antagonist known to be more effective on $\mathrm{mu}$ than delta opiate receptors, reversed the inhibitory effect of DAGO on cAMP production with a higher efficacy than that observed with DTLET. Other selective mu agonists, such as trimu 5 and morphiceptin, inhibited basal adenylate cyclase activity in striatal embryonic neurons with a potency similar to that of DAGO. Our data clearly indicate a coupling of mu receptors with adenylate cyclase in central neurons. It should be recalled that such coupling has been observed in tumor cell line $7315 \mathrm{c}$ (Frey and Kebabian, 1984) and that $\mathrm{mu}$ agonists have been shown to reduce the cAMP efflux from striatal slices of the adult rat (Schoffelmeer et al., 1985, 1987). In addition, it has recently been reported that DAGO inhibits cAMP production in homogenates from the neonatal rat forebrain (Milligan et al., 1987) and the adult guinea pig cochlea (Eybalin et al., 1987).

Electrophysiological studies made in the periphery or CNS indicate that $\mathrm{mu}$ and delta opiate receptors can be colocalized on the same cells (Egan and North, 1981; Zieglgänsberger et al., 1982). Such colocalization of both types of receptors negatively coupled to adenylate cyclase also seems to occur on the same neuronal subpopulation in the striatum of the mouse embryo, since the inhibitory effects of DAGO and DTLET on basal or forskolin stimulated activity of adenylate cyclase were nonadditive. Interestingly, it has been suggested that the different topographic distribution of the mu (striosomes) and delta (diffuse) opiate binding sites in the adult striatum could be modulated by ions and GTP (Bowen et al., 1981) and that these binding sites may be allosterically coupled and may eventually share a common component (Rothman et al., 1985; Bidlack and O'Malley, 1986). According to this model, differences in the ontogeny or regional distribution in the adult of these 2 types of binding sites could be related to some environmental changes in the membrane composition or cellular activity. It should also be pointed out that the density of mu receptors does not change after birth, whereas that of delta receptors increases 40 -fold (Milligan et al., 1987). This difference in the density of mu and delta receptors could explain the much weaker inhibitory effects of DAGO, trimu 5, and morphiceptin on cAMP production in adult striatal membranes compared with that of DTLET.

A recent investigation in the adult rat striatum has suggested the occurrence of heteroregulation between DA D1 receptors and opiate receptors (Schoffelmeer et al., 1986). Our results favor the existence of such heteroregulation and indicate that striatal neurons possessing mu and delta receptors also possess DA D1 receptors. Indeed, the amplitude of the inhibitory effects of DAGO or DTLET was increased in the presence of DA. These results can also be discussed in light of those of Weiss et al. (1985), who reported that the inhibitory effects of opiate and dopaminergic D2 agonists on cAMP production in intact striatal neurons in primary culture were nonadditive. Such a nonadditivity favors colocalization of dopaminergic D2 and opiate receptors on neuronal subpopulations. This allows us to suggest, on the basis of our data, that this subpopulation of striatal neurons possesses D1 and D2 dopaminergic receptors, as well as mu and delta opioid receptors coupled to an adenylate cyclasc. This conclusion may seem to contradict autoradiographic findings indicating a distinct distribution of D1 (striosomes) and D2 (matrix) receptors in the striatum of adult mammals (Joyce et al., 1986; Besson et al., 1988). However, as observed for the inhibitory effects of DAGO or DTLET, we have previously shown that the inhibitory effect of somatostatin on adenylate cyclase activity increases in the presence of DA (Chneiweiss et al., 1985b), indicating colocalization of D1 and somatostatin receptors. Thus, the present results suggest that the D1 receptors are either colocalized with mu and delta opioid receptors or with somatostatin receptors on 2 distinct subpopulations of embryonic striatal neurons. This conclusion is supported by the complete additivity of the inhibitory effects of somatostatin and DAGO or DTLET on basal adenylate cyclase activity.

Besides the striatum, several structures (including the cerebral cortex and mesencephalon) possess delta and mu opiatc binding sites in the adult brain (Quirion et al., 1983; Moskowitz and Goodman, 1984). In fact, the cerebral cortex is one of the structures with the greatest density of delta binding sites. Surprisingly, in contrast to results obtained in the striatum, opiate receptors coupled negatively to adenylate cyclase were not found on embryonic neurons from the cerebral cortex and the mesencephalon in primary culture. This is not due to a delayed appearance of functional adenylate cyclase in these cells, since VIP and somatostatin receptors, respectively, stimulate and inhibit the enzyme in these cells (Chneiweiss et al., 1985a, b). It remains to be determined whether opiate receptors are localized on intrinsic neurons in these structures or whether specific factors are required for the appearance in vitro of functional opiate receptors on neurons from the mesencephalon or cerebral cortex in particular.

During the last few years, an increasing number of functional receptors have been identified on astrocytes (Murphy and Pearce, 1987), and it has been proposed that they could play an important role in the interactions between astrocytes and neurons. This is the case particularly for the VIP receptors coupled to adenylate cyclase that have been characterized on astrocytes from several structures of the mouse brain (Chneiweiss et al., 1985a, 1986). The absence of opiate receptors coupled to adenylate cyclase on astrocytes of all structures examined in the present study suggest that not all neuropeptides are involved in neuron-glia interactions or that opioids may act on glial cells through a second messenger other than cAMP.

\section{References}

Besson, M. J., A. M. Graybiel, and M. A. Nastuk (1988) $\left({ }^{3} \mathrm{H}\right) \mathrm{SCH}$ 32390 binding to D1 dopaminergic receptors in basal ganglia of cat and primate: Delineation of striosomal compartment and pallidal and nigral subdivision. J. Neurosci. (in press).

Bidlack, J. M., and W. E. O'Malley (1986) Inhibition of mu and delta but not kappa-opioid binding to membranes by Fab fragments from 
a monoclonal antibody directed against the opioid receptor. J. Biol Chem. 261: 15844-15849.

Bowen, W. D., S. Gentleman, M. Herkenham, and C. B. Pert (1981) Interconverting $\mathrm{mu}$ and delta forms of the opiate receptor in rat striatal patches. Proc. Natl. Acad. Sci. USA 78: 4818-4822.

Chneiweiss, H., A. Prochiantz, J. Glowinski, and J. Premont (1984) Biogenic amines sensitive adenylate cyclases in primary culture of neuronal or g! ial cells from mesencephalon. Brain Res. 302: 363-370.

Chnciweiss, H., J. Glowinski, and J. Premont (1985a) VIP receptors linked to an adenylate cyclase and their relationship to biogenic amines and somatostatin-sensitive adenylate cyclases on central neuronal and glial cells in primary cultures. J. Neurochem. 44: 779-786.

Chneiweiss, H., J. Glowinski, and J. Premont (1985b) Modulation by monoamines of somatostatin-sensitive adenylate cyclase on neuronal and glial cells from mouse brain in primary cultures. J. Neurochem. 44: $1825-1831$.

Chneiweiss, H., J. Glowinski, and J. Premont (1986) Do secretin and VIP have independent receptors on striatal neurones and glial cells in primary cultures? J. Neurochem. 47: 608-613.

Chneiweiss, H., P. Bertrand, J. Epelbaum, C. Kordon, J. Glowinski, J. Premont, and A. Enjalbert (1987) Somatostatin receptors on cortical neurones and adenohypophysis: Comparison between specific binding and adenylate cyclase inhibition. Eur. J. Pharmacol. 138: 249-255.

Cooper, D. M. F., C. Londos, D. L. Gill and M. Rodbell (1982) Opiate receptor-mediated inhibition of adenylate cyclase in rat striatal plasma membranes. J. Neurochem. 38: 1164-1167.

Di Porzio, U., M. C. Daguet, J. Glowinski, and A. Prochiantz (1980) Effect of striatal cells on in vitro maturation of mesencephalic dopaminergic neurones grown in serum free conditions. Nature 288 : 370-373.

Egan, T. M., and R. A. North (1981) Both mu and delta-opiate receptors exist on the same neuron. Science 214: 923-924.

Eghbali, M., C. Santoro, W. Paredes, E. L. Gardner, and R. S. Zukin (1987) Visualization of multiple opioid receptor types in rat striatum after specific mesencephalic lesions. Proc. Natl. Acad. Sci. USA 84: 6482-6586.

Eybalin, M., R. Pujol, and J. Bockaert (1987) Opioid receptors inhibit the adenylate cyclase in guinea pig cochleas. Brain Res. 421: $336-$ 342.

Frey, E. A., and J. W. Kebabian (1984) A mu-opioid receptor in $7325 \mathrm{c}$ tumor tissue mediates inhibition of immunoreactive prolactine release and adenylate cyclase activity. Endocrinology 115: 1797-1804.

Garbay-Jaureguiberry, C., A. Robichon, V. Dauge, P. Rossignol, and B. Roques (1984) Highly selective photoaffinity labeling of $\mathrm{mu}$ and delta opioid receptors. Proc. Natl. Acad. Sci. USA 81: 7718-7722.

Glowinski, J., and L. L. Iversen (1966) Regional studies of catecholamines in the rat brain. I. Disposition of ${ }^{3} \mathrm{H}$-norepinephrine, ${ }^{3} \mathrm{H}$ dopamine and ${ }^{3} \mathrm{H}-\mathrm{DOOPA}$ in various regions of the brain. J. Neurochem. 13: 655-669.

Goodman, R. R., S. H. Snyder, M. Kuhar, and W. S. Young (1980) Differentiation of $\mathrm{mu}$ and delta opiate receptor localizations by light microscopic autoradiography. Proc. Natl. Acad. Sci. USA 77: 62396243.

Handa, B. K., A. C. Cane, J. A. H. Lord, B. A. Morgan, M. J. Rance, and C. F. C. Smith (1981) Analogues of $\beta-\mathrm{LPH}_{61-64}$ processing selective against activity of mu-opiate receptors. Eur. J. Pharmacol. 70 : $531-540$.

Herkenham, M., and C. B. Pert (1981) Mosaic distribution of opiate receptors, parafascicular projections and acetylcholinesterase in rat striatum. Nature 291: 415-417.

Joyce, J. N., D. W. Sapp, and J. F. Marshall (1986) Human striatal dopamine receptors are organized in compartments. Proc. Natl. Acad. Sci. USA 83: 8002-8006.

Law, P. Y., J. Wu, J. Koehler, and H. H. Loh (1981) Demonstration and characterization of opiate inhibition of the striatal adenylate cyclase. J. Neurochem. 36: 1834-1846.

Law, P. Y., D. S. Hom, and H. H. Loh (1985) Multiple affinity states of opiate receptor in Neuroblastoma $\times$ Glioma NG108-15 hybrid cells. J. Biol. Chem. 260: 3561-3569.
Leslie, F. M. (1987) Methods used in the study of opioids. Pharmacol. Rev. 39: 197-249.

Lord, J. A. H., A. A. Waterfield, J. Hughes, and H. W. Kosterlitz (1977) Endogenous opioid peptides: Multiple agonists and receptors. Nature 267: 495-499.

Martin, W. R. (1984) The pharmacology of opioids. Pharmacol. Rev. 35: 283-323.

Milligan, G., R. A. Streaty, P. Gierschik, A. M. Spiegel, and W. A. Klee (1987) Development of opiate receptors and GTP-binding regulatory proteins in neonatal rat brain. J. Biol. Chem. 262: 8626-8630.

Moskowitz, A. S., and R. R. Goodman (1984) Light microscopic autoradiographic localization of mu- and delta-opioid binding sites in the mouse central nervous system. J. Neurosci. 4: 1331-1342.

Murphy, S., and B. Pearce (1987) Functional receptors for neurotransmitters on astroglial cells. Neuroscience 22: 381-394.

North, R. A. (1986) Opioid receptor types and membrane ion channels. Trends Neurosci. 9: 114-117.

Paterson, S. J., L. E. Robson, and H. W. Kosterlitz (1983) Classification of opioid receptors. Br. Med. Bull. 39: 31-36.

Piercey, P. F., R. A. I.ahti, I. A. Schroeder, F. J. Einspahr, and C. Barsuhn (1982) U $50488 \mathrm{H}$, a pure kappa receptor agonist with spinal analgesic loci in the mouse. Life Sci. 31: 1197-1200.

Premont, J., M. C. Daguet de Montety, A. Herbet, J. Glowinski, J. Bockaert, and A. Prochiantz (1983) Biogenic amines and adenosine sensitive adenylate cyclases on striatal neurones. Dev. Brain Res. 9: 53-61.

Prochiantz, A., A. Delacourte, M. C. Daguet, and D. Paulin (1982) Intermediate filament proteins in mouse brain cells cultured in the presence or absence of fetal calf serum. Exp. Cell Res. 139: 404-410.

Quirion, R., J. M. Zajac, J. L. Morgat, and B. P. Roques (1983) Autoradiographic distribution of $\mathrm{mu}$ and delta opiate receptors in rat brain using highly selective ligands. Life Sci. Suppl. I 227-230.

Rothman, R. B., W. D. Bowen, M. Herkenham, A. E. Jacobson, K. C. Rice, and C. B. Pert (1985) A quantitative study of ${ }^{3} \mathrm{H}\left(\mathrm{D}-\mathrm{Ala}{ }^{2}\right.$-D$\mathrm{Leu}^{5}$ ) enkephalin binding to rat brain membranes; evidence that exomorphine is a non-competitive inhibitor of the lower affinity deltabinding site. Mol. Pharmacol. 27: 399-408.

Salomon, Y., C. Londos, and M. Rodbell (1974) A highly sensitive adenylate cyclase assay. Anal. Biochem. 58: 541-548.

Schoffelmeer, A. N. M., H. A. Hansen, J. C. Stoof, and A. H. Mulder (1985) Inhibition of dopamine-stimulated cyclic AMP efflux from rat neostriatal slices by activation of $\mathrm{mu}$ - and delta-opioid receptors. Eur. J. Pharmacol. 118: 363-366.

Schoffelmeer, A. N. M., H. A. Hansen, J. C. Stoof, and A. H. Mulder (1986) Blockade of dopamine D2 receptors strongly enhances the potency of enkephalins to inhibit dopamine-sensitive adenylate cyclase in rat neostriatum: Involvement of mu- and delta-opioid receptors. J. Neurosci. 6: 2235-2239.

Schoffelmeer, A. N. M., F. Hogenboom, and A. H. Mulder (1987) Inhibition of dopamine-sensitive adenylate cyclase by opioids: Possible involvement of physically associated mu- and delta-opioid receptors. Nanyn Schmiedberg's Arch Pharmacol. 335: 278-284.

Sharma, S. K., M. Nirenberg, and W. A. Klee (1975) Morphine receptors as regulators of adenylate cyclase activity. Proc. Natl. Acad. Sci. USA 72: $590-594$

Simon, E. J. (1987) Subunit structure and purification of opioid receptors. J. Receptor Res. 7: 105-132.

Weiss, S., M. Sebben, J. A. Garcia-Sainz, and J. Bockaert (1985) D2dopamine receptor mediated inhibition of cyclic AMP formation in striatal neurons in primary culture. Mol. Pharmacol. 27: 595-599.

Zajac, S. M., and B. P. Roques (1985) Differences in binding properties of mu- and delta-opioid receptor subtypes from rat brain: Kinetic analysis and effects of ions and nucleotides. J. Neurochem. 44: 16051614.

Zieglgänsberger, W., E. D. French, N. Merecuri, F. Pelayo, and J. T. Williams (1982) Multiple opiate receptors on neurons of the mammalian central nervous system. In vivo and in vitro studies. Life Sci. 31: $2343-2346$. 